\title{
Harry White \& Barra Boydell (eds.), Encyclopaedia of Music in Ireland
}

\section{Erick Falc'her-Poyroux}

\section{(2) OpenEdition \\ 1 Journals}

\section{Electronic version}

URL: https://journals.openedition.org/etudesirlandaises/3857

DOI: 10.4000/etudesirlandaises.3857

ISSN: 2259-8863

\section{Publisher}

Presses universitaires de Caen

\section{Printed version}

Date of publication: 30 June 2014

Number of pages: $231-232$

ISBN: 978-2-7535-3449-0

ISSN: 0183-973X

\section{Electronic reference}

Erick Falc'her-Poyroux, "Harry White \& Barra Boydell (eds.), Encyclopaedia of Music in Ireland", Études irlandaises [Online], 39-1 | 2014, Online since 30 June 2016, connection on 20 April 2022. URL: http:// journals.openedition.org/etudesirlandaises/3857 ; DOI: https://doi.org/10.4000/etudesirlandaises. 3857

\section{(c) (1) ()}

Études irlandaises est mise à disposition selon les termes de la Licence Creative Commons Attribution - Pas d'Utilisation Commerciale - Partage dans les Mêmes Conditions 4.0 International. 
those readings can be given a particular colouring thanks to the voice, the "signature" of a particular journalist. Here an obvious example is someone like Sorj Chalendon who pushes Liberration's idealisation of the republican cause on to the level of a personal crusade. Another example would be René Fréchet, the wellknown Irish Studies specialist who lectured at Paris 3 and who covered Northern Ireland for the French Protestant weekly, Réforme. Fréchet is worth mentioning in that he was often a lone voice on the North choosing as he did to go against received wisdom and the dominant prêts-à-penser to look at the concerns of the unionist community in a more balanced, less caricatural light than many of his colleagues.

Thus, Deslandes' attention to political and cultural subtexts, her sensitivity to the multiplicity of possible readings of a given situation and her ability to work on the interface between two evolving political realities make the book a most valuable contribution to work in French on the Northern Ireland conflict. It is certain to stimulate further research in an area which has not received sufficient attention.

Wesley Hutchinson

Université Sorbonne Nouvelle-Paris 3

Harry White \& Barra Boydell (eds.), Encyclopaedia of Music in Ireland, Dublin, UCD Press, 2013, 1152 p., ISBN 978-1-90635-978-2

Over ten years in the making, the Encyclopaedia of Music in Ireland (EMIR), is one of the many projects made possible by the Irish-American businessman Chuck Feeney, and notably co-funded by the Irish Research Council. Inspired by the 1980 New Grove Dictionary of Music and Musicians, and the 1981 Encyclopedia of Music in Canada, it aims at being "the first comprehensive attempt to chart Irish musical life across recorded history", and was edited by two of the most distinguished professors of music in Ireland, Harry White and Barra Boydell.

With 2000 articles written by 240 contributors for two volumes, printed on quality paper and presented in a splendid hard case, EMIR has been several times described by the authors themselves as a "map of Irish musical experience", albeit "not an exhaustive index or directory": the selection process was thus a challenging and lengthy one, completed by a board of editors chaired by Gerard Gillen, another distinguished professor of Music in Ireland, on the basis of "musical significance rather than fame", as summed up by Harry White. 
One of the great ideas on which this Encyclopaedia was built is indeed the inclusion, not only of names of people, places and institutions, but also of the most important concepts at work in the field of music in Ireland. We thus find very instructive and readable entries on "education" (three pages), "identity" (two pages), "tourism" (one page), etc. The choice of headwords, however, curiously results in the presence of a nine-page section on "Traditional music and song", a two-page section on "Jazz", a one-page section on "Rock music and Rock'n'roll", but forgets to mention "Classical music" as a separate entry, and this leaves the critic genuinely wondering why? Not that the genre is absent from the Encyclopaedia, on the contrary: it has been calculated (by F. Vallely) that $65 \%$ of the material is of "Classical, Church and Musicology" while 25\% is devoted to Traditional Irish music, and 6\% to modern Popular and Rock music.

A minor quarrel has thus erupted regarding the possible bias of the editors of EMIR in favour of Classical Music, with the rather intriguing omissions of entries on Comhaltas Ceoltóirí Éireann's Director Labhrás Ó Murchú, on the ecumenical but incisive Journal of Music, on Hot Press editor Niall Stokes, or on Antrim trad band "Déanta", certainly as influential as "Nomos", but not emanating from a famous music department in the Republic. It is true that Traditional music and Popular music are under-represented in this set of two volumes, but probably also true that the editors are consciously trying to redress the international imbalance in favour of classical music from Ireland, whether one approves of or opposes the choices made.

Overall, this book represents a monumental sum of knowledge by the most authoritative voices in the field of music in Ireland, from Ann Buckley and Nicolas Carolan to Mícheál Ó Súilleabháin, Joseph Ryan and Gerry Smyth, spanning both the entire history of the country and the entire spectrum of musical genres. One would be hard pressed to find fault with the first edition of such a landmark book in the musical history of Ireland, and it should be remembered that Harry White himself was fully aware that "an encyclopaedia, the moment it appears, is prone for revision, or subsequent editions". It is thus hoped that, like for its predecessor, the Encyclopedia of Music in Canada, the editors of this extraordinary new Encyclopaedia will quickly realise they need to offer free online access to EMIR and regularly update it.

What we have in our hands here is not only an outstanding description and analysis of a country's musical life, it is a landmark contribution to the understanding of Ireland.

Erick FalC'her-Poyroux

Université de Nantes 